Journal of Southeast Asian

2013

\title{
Teach Me: A Narrative Collage
}

May Chang

American Public University System, maykhang@hotmail.com

Follow this and additional works at: https://docs.lib.purdue.edu/jsaaea

\section{Recommended Citation}

Chang, May (2013) "Teach Me: A Narrative Collage," Journal of Southeast Asian American Education and Advancement: Vol. 8 : Iss. 1, Article 12.

DOI: $10.7771 / 2153-8999.1067$

Available at: https://docs.lib.purdue.edu/jsaaea/vol8/iss1/12

This document has been made available through Purdue e-Pubs, a service of the Purdue University Libraries. Please contact epubs@purdue.edu for additional information.

This is an Open Access journal. This means that it uses a funding model that does not charge readers or their institutions for access. Readers may freely read, download, copy, distribute, print, search, or link to the full texts of articles. This journal is covered under the CC BY-NC-ND license. 


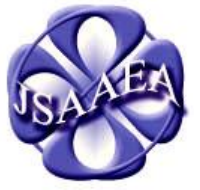

Volume 8 (2013)

\section{Journal of Southeast Asian American \\ Education \& Advancement \\ WWW.JSAAEA.org}

A peer-reviewed

scholarly journal

published by the

National Association

for the Education \&

Advancement of

Cambodian, Laotian, and Vietnamese Americans (NAFEA)

\title{
TEACH ME
}

\author{
by \\ May Chang \\ American Public University System
}

* Names of people and places have been changed.

\section{Margaret}

My dad tells me to speak when the teachers ask me questions. "They're testing you to see if you're ready for school," he says. I don't know why, but I don't say a word to any of the white ladies. I sit in the little plastic chair and look at my hands. My dad sighs and tries to talk to one of the ladies. His talk comes in the form of exaggerated gestures and bits of Hmong and English interspersed. The lady shakes her head. My dad takes me back home. While my older brother and sister go off to school, I sit on the stairs of the front porch and wish I could go to school too. I open the empty palms of my hands so they resemble a book, and I pretend to read. My lips move silently as I form words in my mouth, the way I've seen my brother do when he reads.

I start school a year later than all the other kids my age. A yellow bus picks me up and takes me to my kindergarten class. In the afternoon, another bus takes me to another school so I can be in first grade with kids my age.

The floor in my kindergarten classroom is covered in thin, gray carpeting, like pants worn out at the knee. The bulletin boards are bright and colorful. One of them has a weather chart tacked on, and the other has cut-outs of jungle animals with books, pencils, crayons, and papers. It looks like a cheerful place, but I don't like being there.

My teacher's name is Margaret, and she makes me sit in the corner by myself. All morning, I watch her sit in a circle with the other kids and read or sing songs with them. After Christmas break, she finally invites me to join the circle while all the other kids do show-and-tell with the toys they got for Christmas. When it's nearing my turn, I think about pulling out my purple My Little Pony from my sweatshirt pocket. Maybe I'll tell them my parents gave it to me for Christmas, even though it came wrapped in thin tissue paper from the Catholic Church down the street. But when it's my turn, Margaret says, "Oh, you people don't celebrate Christmas." She skips me and goes to the little red-haired girl on my right. All year, I sit in my corner and look at my hands. They're browner than everyone else's.

\footnotetext{
(c)

SOMERIGHISRESERVEDReaders are free to copy, display, and distribute this article, as long as the work is attributed to the author(s) and the Journal of Southeast Asian American Education \& Advancement, it is distributed for noncommercial purposes only, and no alteration or transformation is made in the work. More details of this Creative Commons license are available at http://creativecommons.org/licenses/by-nc-nd/3.0/. All other uses must be approved by the author(s) or JSAAEA.
} 


\section{Second Grade}

I can never remember the names of any of my second grade teachers because my family moves so much in one year. I start second grade at Spencer Elementary, then we move to an old farmhouse on the outskirts of town and I go to a small school with only five teachers, then we move back into town and I'm at yet another school, this time Belle Elementary. I'm so quiet the teachers aren't sure if I know any English. Some of them speak loudly and slowly to me. They make weird gestures with their hands to help me understand. They want to know if I need help with anything. Finally, they decide to pull me out for ESL class.

On parent-teacher conference night, my parents decide to go. They make the rounds to each of their children's teachers. At the end of the night, my parents come back with their arms full of projects, tests, and assignments. "What did my teacher say about me?" I ask. My parents look at one another. Finally my dad says, "Zoo heev. Good. All your teachers are nice. They said great things about you." "And? What else?" my brother asks. My mom shrugs her shoulders. She says, "Your dad and I didn't understand the rest of what they said. But they smile a lot. They're very nice people."

\section{Mr. Wells}

My third grade teacher is named Mr. Wells. He has beanbags placed in one corner of his room. It's divided from the rest of the class by a waist-high fence made to look like oversized, red pencils. We all want to sit there for reading time, but we have to earn enough points first. At the end of the day, Mr. Wells likes to take us outside to run around the perimeter of the kickball field. He races with us and says that whoever beats him gets to sit on the beanbags all week during reading time. I'm fast, and I almost beat him a few times.

One rainy day, Mr. Wells starts reading aloud a book to us because we can't go out for recess. The book is called, The Indian in the Cupboard. I like the story so much I want him to keep reading until it's finished. He reads one or two chapters to us a day, and when the book is done, I'm so fascinated I want to read another book for the same effect. It feels supernatural, like I'm floating around from one character to the next, from one world to another. In books, I fit right in.

During library hour, I find five books I want to read, but the librarian says kids can only check out three books at a time. I start reading so much at home my parents decide I don't have to do my chores. "Let her read. She's doing homework," they say. Anything with a book is homework to them. But really, I'm just reading because I want to.

It gets easier and easier to read, and pretty soon, I'm also really good at spelling. Mr. Wells asks everyone in class to spell "biscuit," and I'm the only one who does it right. He puts me in the spelling bee at my school, and I win. At the next level of competition, I stand in a long line of contestants in front of three judges and a small crowd of people. The event is in a stuffy cafeteria that smells like meat loaf. When it's my turn, one of the judges tells me to spell "whether," but I spell "weather" instead and lose. I ask Mr. Wells, "Why do some American words sound the same but are spelled different and mean different things?" He says it's probably because a long time ago, a group of all-important men sat together at a table and decided to make English confusing. He does the air quotations with his fingers when he says "all-important." Then he says, "You did a great job in that spelling bee. Better than a lot of kids who've known 
English all their life and still can't spell." I think about what he says and decide I'd rather be those white kids who can't spell than be a Hmong kid who can.

\section{Mrs. Adams}

Mrs. Adams says we're going to have a Christmas gift exchange on the last day before winter break. My parents don't have much money, so my dad goes to Goodwill to buy Little Golden Books that cost five cents each. I don't want to bring these books in as my present to a peer, because they're too childish for fourth graders. They're also too cheap. I cry about it at home and make a big scene, but my dad says he can't do anything about it - he has no money. So finally, I wrap two of the books together. One is called The Poky Little Puppy and the other one is called Tootle. During the Christmas exchange, I pick Sherry's name out of the hat so I have to give my present to her. The second I hand it to her, she pouts. "I don't want this present! I already know what it is. It's a book, and I don't want stupid books," she hollers. She throws the present back at me. I saunter to my desk and sink into the chair, my face burning red like the globe ornaments on the classroom's little Christmas tree. Mrs. Adams takes Sherry by the arm, drags her out into the hallway, and scolds her. "You be polite. Not everybody can afford nice gifts," Mrs. Adams says. Her voice echoes into the classroom. I can hear her clearly, and so can everybody else in class.

\section{The Red Pick-up Truck}

One morning, my mom wakes me up before all my other siblings. It's the day of my fifth grade class field trip to the state capitol, and Mrs. Martin says we all need to be at school by 6:45 a.m. My mom can't send me, because she doesn't know how to drive. My dad is gone somewhere. It's raining, so my mom gives me an umbrella. She glances out the window and sees that it's dark and wet. She looks worried, but she sends me out anyway, and says, "Ceev faj. Be careful." I'm scared because I've always walked to school with my siblings, and everything this morning looks spooky and different in the gloom.

When I'm halfway to school, I see a red pick-up truck slowly following me. I try peering shrewdly into the truck to see who's inside, but the windows are tinted so dark that it's like looking into a glossy lake at night. The truck follows me and stops when it's right next to me. Then it waits for me to walk further ahead before it drives slowly to catch up to me again. It does this for blocks.

My heart pounds, and I'm mad at my mom for staying home with my siblings instead of walking with me. I'm mad at my dad for being somewhere else instead of driving me. I start to run and run so fast that I could definitely beat Mr. Wells if he were here. Finally, I see my school two blocks away, and Mrs. Martin is standing next to the bus driver by the yellow bus. I turn around to look behind me. The red truck turns a corner and disappears.

\section{Mrs. Taylor}

In sixth grade, all the Hmong kids including me are put into Mrs. Taylor's class. Last year, we were all in Mrs. Martin's class. At recess, my cousin says it's because some of the teachers don't want to teach Hmong students. I don't mind, because it means I get to be with my cousins. It also means the teachers who take us are always nice. Mrs. Taylor is nice, even though her first name is Margaret, like my kindergarten teacher's. 
In the classroom, the desks are arranged in groups of four or five. The bulletin boards display themes like the solar system and the stages of the writing process. There is one computer in the room, a relatively new technology. We're excited when we have assignments that give us reasons to clack away on the keyboard. When we're done, we save our work on thin, flimsy disks that Mrs. Taylor calls, "floppies."

Mrs. Taylor likes to learn about the Hmong culture. "What kind of food do you eat at home?" she says. We tell her about eggrolls dipped in peanut butter sauce, curry soup, and purple sticky rice. "How do you greet each other in Hmong?" she asks. "Nyob zoo. It sounds like this: nyah zhoong," we say. She repeats after us, and we commend her on her pronunciation.

One day, Mrs. Taylor is very sad. We ask her what happened, and she says her husband is dying from cancer. She has to explain what cancer is, because we don't have a word for it in Hmong. When a person gets sick, we've been taught at home that it's usually a result of the person's spirit having wandered away, not because of things like abnormal cells growing out of control. I tell Mrs. Taylor that she and her husband should watch Home Alone, because it'll make them laugh and forget about cancer.

In the spring, Mrs. Taylor's husband dies and we have a sub for a week. We make cards for her, and then we work on writing stories. Mine turns out to be pages about a girl who spills weird chemicals on herself during a science experiment. Later, she finds out she has the ability to change into a cat, except that it happens when she doesn't want it to. I title it, "Half-Girl, HalfCat." The sub gives me a curious look when she reads my story. "Did you really write this? Because if you did, you should enter this in the school's writing contest," she says. I don't really want to, because if I win first place, I have to read my story in front of the whole school. When Mrs. Taylor comes back, I show her my story. She also encourages me to enter it in the contest, so I decide to do it.

During the school assembly, I'm so nervous I can hardly focus on anything. All I can think about is: what if I really do win first place and have to read my story in front of everyone? The gym is noisy with kids talking, laughing, and shuffling their feet on the bleachers. One of the teachers blows his whistle-BLEEP, BLEEP - and the whole gym goes quiet. Finally, the principal makes a speech and announces the winners of the contest. It turns out that I've won second place. I get a certificate and a rigorous handshake from the principal. It feels good, maybe even better, than winning first place.

\section{South Junior High School}

In junior high, the classrooms are not as brightly decorated, and the desks are all in straight rows. Time is dictated by the sound of the school bell ringing. One day, with ten minutes left in class, my home economics teacher asks what our parents do for a living. We're studying careers, and so she makes everyone share. All of my classmates' parents have cool jobs, like engineer, construction worker, or salesperson. I don't want everyone to know my dad works in a slaughter house and kills pigs for a living. I don't want them to know my mom gets assistance from the state. So what I say is that I have a stay-at-home mom and a dad who is a soldier, which is partly true. Or was true.

I know a little bit about my dad's past, that he was a lieutenant colonel in Laos. He led a platoon of soldiers to rescue downed American pilots and block the Ho Chi Minh Trail during the Vietnam War. But now he's just a refugee who works at a pig slaughter house. He drives an hour every day to work, and when he comes home, he smells of pig. He has splashes of blood 
and grease on his clothes, hair, and skin, as if he's just come back fresh from a real war. Some days he brings home a plastic bag full of pig parts that nobody else wants, and that's how we save money by not having to buy meat.

\section{Miss Nadelbach}

I have a first year teacher, whom we call, "Mrs. N." for eighth grade social studies. She has wild ideas for lessons. We spend a week building a train model. Pretty soon, the project turns into months in which we're building a whole town around our train model. Mrs. N. brings in little booklets from a company that sells model kits and says each person can buy one building to add to our town. I choose a lighthouse because it's only three dollars. When it arrives, I construct it and place it on the town's edge. The whole town grows to take up half our classroom.

When we're finally done building our town, Mrs. N. makes us sit at our desks, except we're all crowded together on one side of the room and we can barely move. Mrs. N. makes us write about what we want our new town to be like. We can write about anything we want. So I write this: I want our town to be open. I want everybody to get along and not have disagreements. If somebody doesn't understand somebody else, they shouldn't be so quick to judge. They should take the time to talk to the other person and try to understand.

Mrs. N. glances around the room at everybody's paper and says, "Now make sure you include examples of what you mean." So then I add this: For example, you shouldn't believe everything you hear. Some people think Hmong eat cats and dogs but that's just a rumor. I'm Hmong and I don't know of anyone my race who eats cats and dogs. I think the rumor started because some people didn't take the time to talk to us to understand our culture. I also don't think it's fair to think everybody of one race is the same. Jeffrey Dahmer is a white American and he ate people. Does that mean every white American eats people too? No. It's not right to judge. So that's why I want our model town to be more open to others.

The next day, I see Mrs. N. in the hallway before class. She wants me to read my paper aloud, but I tell her that she can read it if she wants, but only if she doesn't say who wrote it. Just as she starts reading it to the class, I realize everyone will know who wrote it anyway: I'm the only Hmong student in class.

\section{Rosemont High School}

In tenth grade, I start hanging out with other people besides my cousins. I have a small group of white friends who I sit with every day for lunch. They bring brown paper sacks that usually contain ham sandwiches, soda, yogurt, apple slices, and cookies. I feel different being the only one with a free hot lunch, so some days I don't bother waiting in the lunch line. On those days, my friends share food with me.

I don't sit at the Hmong table anymore. My cousins get mad and call me a "white wannabe." They also call me a "twinkie" because they say no matter how white I try to be on the inside, I'm always going to have yellow skin. I don't care though, because being with my white friends means I don't get paper wads thrown at me anymore.

In English class, my teacher shows us a poem she's published. I'm amazed that she's a real published writer. I change my career goal from social worker to writer. I start a notebook in which I write stories. My favorite one is about a girl named Brandy whose family moves into a big Victorian house that's haunted. Brandy hears strange noises in the basement, so one day she 
decides to investigate. Buried among basement junk, she finds a box full of items: An old Raggedy Ann doll, a friendship necklace, and a diary. She also finds an old newspaper clipping about a girl who suddenly disappeared and was never found. Brandy starts to see a ghost girl who's trying to tell her something. Finally, at the end of the story, Brandy figures out from all the clues that the girl was murdered by her own father. She follows a strange crying that leads her to a tree in the backyard. She starts to dig and dig until she finds something. Bones. Human bones.

\section{American Dream Class}

"What is the American Dream? What is your American Dream? I'd like to see copious paragraphs, folks," Mr. Evans says. He's always telling us to do everything copiously - take copious notes, read and write copiously. I write about college, although I haven't really thought about going. Mr. Evans asks me if I've taken the ACT, but I haven't. He asks if I've thought about which college, if I've filled out the financial aid forms, if I've asked people to write me recommendation letters, but I haven't done any of those things either. "Why not?" he says. I shrug my shoulders. Simply put, I've never been exposed to the process of going to college.

The next day, I ask my dad to write a check for me to register for the ACT. "Do I look like I have money?" he says. I don't blame him for his response. There are two reasons why. One, money is always an issue in my family. And two, my recent bouts of teenage rebellion have angered and frustrated my dad. But I keep bothering him about the money, because although none of my cousins are planning for college, it's all my white friends are talking about. I want to be like my white friends. After two weeks, my dad finally gives me the money to register for the test.

When I get my test score back, I don't know what it means. I'm doubtful I did well, because after registering for the test, I completely forget about it. But I show my test results to Mr. Evans. "That's good," he says. I ask, "Does that mean I get to go to college?" Mr. Evans pats my back and says, "It means you have a great chance of getting into college." I smile, because it's the first time I have proof that I can make it in college.

\section{English 101 and 102}

I enter college knowing for certain that I'm going to major in English. But when Professor Griffith hands back my first essay in English 101, I see that she's written at the top, "This is NOT what I call college writing." The D grade on the last page makes me cringe. I start to worry that I'm in the wrong major, that maybe I'm not even supposed to be in college. What's a Hmong girl doing majoring in English when it's not even her first language? But I keep working hard and by the end of the semester, I earn a $\mathrm{C}$ in her class.

English 102 is all about research methods and research papers. It's a lot harder than English 101. But for some reason, I'm doing a lot better in this class. One day, I'm the first one to walk into the classroom. Professor Lawrence looks up from his stack of papers and greets me. Then he says, "So what are you planning to do with your English degree?" I'm a little taken aback, because I haven't thought that far ahead. Professor Lawrence says, "You know what I was thinking? You'd make a great English teacher." I frown in surprise at his remark. "Really? Are you sure?" I ask. Professor Lawrence nods his head. "You're smart, you've got a good head on your shoulders, you work hard, and you're patient. I think you can help a lot of kids." I'm still 
too shocked, but I let what he says float around in my head. Me? A teacher? I think about it all semester.

\section{Professor Pazinski}

Professor Pazinski frustrates me. I spend hours and hours writing essays for his class, and I feel pretty confident I deserve an A. But every paper he hands back to me is always a B+ or an A-, never a solid A. He always finds something to critique about my essays, no matter how minor it is. It's maddening, because then I have to force myself to pay attention to every little detail in my essays. If I don't, he'll pick it out and deduct points. And yet I sign up for another one of his classes. And when I'm done with that class, I sign up for a third one.

One day, we're doing writers workshop, and it's my turn. I'm up at the podium in front of the whole class. I have to stand there the entire time while Professor Pazinski and my peers critique my essay. They talk about the tone. They mention the use of a simile that could be revised. Then Professor Pazinski turns everybody's attention to page three. "Did anybody notice the shift in verb tense from past to present on this page? It's very subtle, barely noticeable," he says to the class. Then he turns to me and asks, "Why did you change the verb tense?" I fiddle nervously with the pen in my hand. Then I explain. "That scene is really important. I was trying to give it a sense of immediacy, so it feels like it's happening right now," I say. Professor Pazinski nods and says, "Well-done. You've switched in and out of present tense quite seamlessly. I knew there was a sophisticated writer in you after all."

It isn't until a long time afterwards that I realize the potential he saw in me.

\section{Becoming a Teacher}

I decide to major in English Education and minor in Writing. Everybody says education majors take at least five years to finish their degree, but I've decided I'm going to do it in four years. I take credit overload during some semesters, and I take one or two classes every summer.

Finally, at the start of my fourth year of college, I'm placed in an eighth grade classroom to observe. The kids are antsy and loud. Frankly, they kind of scare me. When I finally go up in front of the class to teach them my very first lesson, I'm so nervous that I stammer and stutter. They roll their eyes, but I continue on with my lesson anyway. I talk about narrative writing and give them an example. As they work on a story map for their own narrative essay, I look around the room. Some are busy writing, their pencils scratching away on paper. Others are staring off into space. I walk over and tap the desks of the ones who are staring. "Let me help you get started," I say. "List all the important events in your life. Vacations? Birth or death of someone you know? Ever broken a bone? Met anyone who changed your life?"

It's the last semester before I graduate, and there's only one teaching internship being offered. Many of my peers are going for it. Everyone else will end up with an unpaid student teaching placement. I don't think I have much of a chance at getting the job because there are so many people being interviewed, but I go in for it anyway.

A week later, the principal of the school calls me up and offers me the job. I'm surprised but absolutely thrilled. I go in to meet my cooperating teacher. She teaches at the school, but she also has a second job in which she travels all over the country doing presentations. When she's gone, which is half of the time, I'll be solely in charge of teaching four classes of seventh and eighth graders and supervising one study hall session. I'm a bit bewildered, because I have never 
yet been the sole person in charge of students. The cooperating teachers I've been with have always stayed in the classroom to help out.

On my first day alone with the students, I'm nervous. I can see in their eyes that they know how I feel. So I force myself to smile. I shake out the tension in my shoulders. I walk around the room, greeting students and talking to them about their day. Eventually, I start the day's lesson on the story of King Midas with the golden touch. I have the students do an anticipation guide, and we start talking about wealth and greed. Hands go up all over the classroom - there are so many things the kids want to share. I read the story aloud to start them off, and then I tell them to finish reading it on their own. Soon, I'm no longer nervous.

In the quietness of the classroom, I look around and see the bent heads of the students, their eyes flowing from the left of the page to the right as they read. A couple of them move their lips silently while reading. And it reminds me of the same way I used to move my own lips when I was a young child pretending to read on the front steps of my porch, wanting so desperately to be worthy of an education. And now, not only have I learned my worth as a student, but I know my worth as a teacher.

\begin{abstract}
About the Author
May Chang is an educator with experience at the middle school, high school, and college levels. She is currently teaching writing and literature at American Public University System. She has a Master's in English from the University of Wisconsin-Oshkosh and a Bachelor's in English Education and Writing from the University of Wisconsin-Stevens Point. She is also currently working on a Master's in Business Administration from American Public University. She lives in Wisconsin with her husband and three children.
\end{abstract}




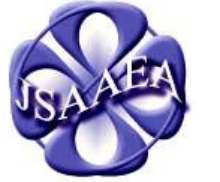

Volume 8 (2013)

\section{Journal of Southeast Asian American Education \& Advancement} WWW.JSAAEA.org

\section{Editor}

Dr. Wayne E. Wright

University of Texas at San Antonio

Associate Editors

Dr. Chhany Sak-Humphry

University of Hawaii at Manoa

Dr. Phitsamay Sychitkokhong Uy

University of Massachusetts, Lowell

Book Review Editor

Dr. Vichet Chhuon

University of Minnesota

Creative Works Editor

Bryan Thao Worra

Lao Assistance Center

Special Advisor

Gregory Green

Curator, Echols Collection on Southeast Asia, Cornell University Library

Journal Manager

Yeng Yang

University of Texas at San Antonio
A peer-reviewed

scholarly journal

published by the

National Association

for the Education \&

Advancement of

Cambodian, Laotian,

and Vietnamese

Americans (NAFEA)

Comments and questions for the editorial staff may be directed to jsaaea@ lists.sis.utsa.edu

\section{Editorial Review Board}

Dr. Steve Arounsack

California State University, Stanislaus

Dr. Phala Chea

Lowell Public Schools

Dr. Loan Dao

University of Massachusetts, Boston

Dr. Changming Duan

University of Missouri, Kansas City

Dr. Jeremy Hein

University of Wisconsin - Eau Claire

Dr. Samlong Inthaly

Minneapolis Public Schools

Dr. Ketmani Kouanchao

Mr. San Jacinto College
Dr. Carl L. Bankston III

Tulane University

Dr. George Chigas

University of Massachusetts, Lowell

Dr. Hien Duc Do

San Jose State University

Dr. Sophal Ear

U.S. Naval Postgraduate School

Dr. Nancy H. Hornberger

University of Pennsylvania

Dr. Peter Nien-Chu Kiang

University of Massachusetts, Boston

Dr. Kevin K. Kumashiro

University of Illinois, Chicago 


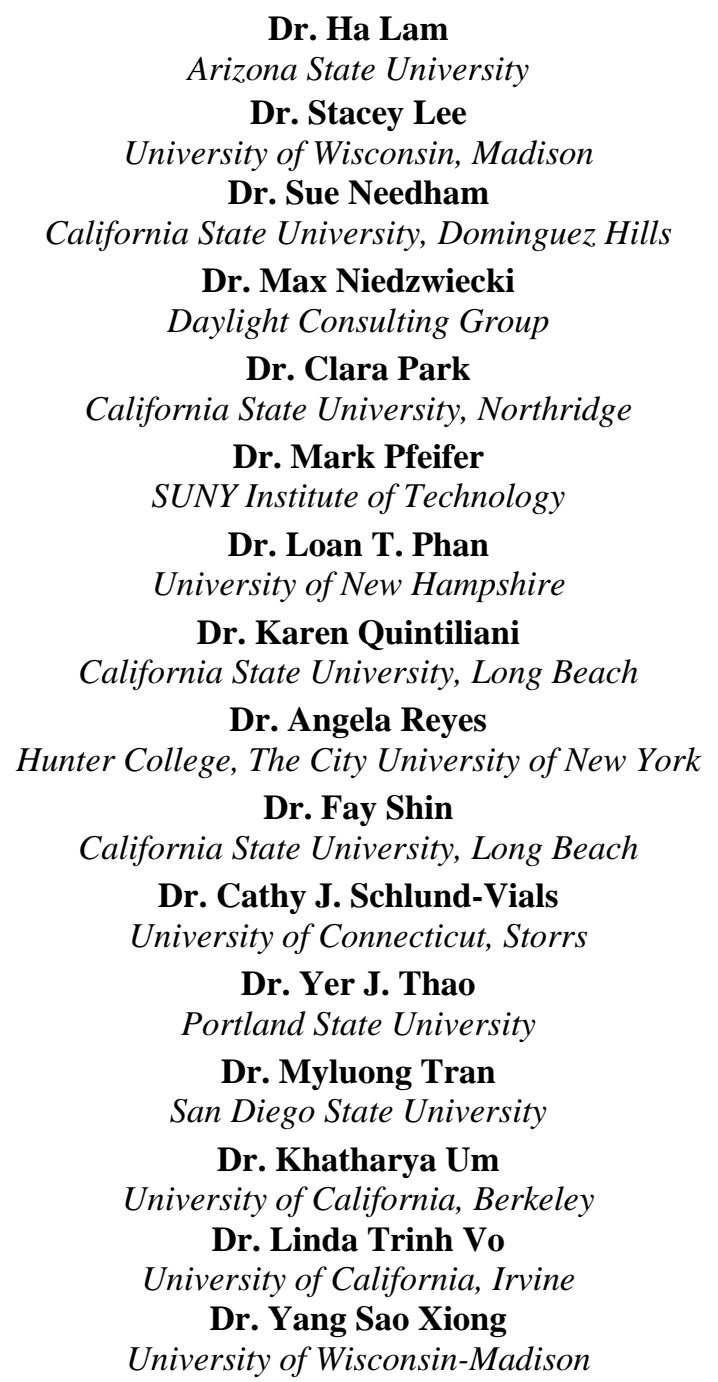

Dr. Ha Lam

Arizona State University

Dr. Stacey Lee

University of Wisconsin, Madison

Dr. Sue Needham

California State University, Dominguez Hills

Dr. Max Niedzwiecki

Daylight Consulting Group

Dr. Clara Park

California State University, Northridge

Dr. Mark Pfeifer

SUNY Institute of Technology

Dr. Loan T. Phan

University of New Hampshire

Dr. Karen Quintiliani

California State University, Long Beach

Dr. Angela Reyes

Hunter College, The City University of New York

Dr. Fay Shin

California State University, Long Beach

Dr. Cathy J. Schlund-Vials

University of Connecticut, Storrs

Dr. Yer J. Thao

Portland State University

Dr. Myluong Tran

San Diego State University

Dr. Khatharya Um

University of California, Berkeley

Dr. Linda Trinh Vo

University of California, Irvine

Dr. Yang Sao Xiong

University of Wisconsin-Madison

Dr. Jonathan H. X. Lee

San Francisco State University

Dr. Monirith Ly

Texas State University-San Marcos

Dr. Bic Ngo

University of Minnesota

Dr. Leakhena Nou

California State University, Long Beach

Dr. Isabelle Thuy Pelaud

San Francisco State University

Dr. Giang Pham

University of Minnesota

Dr. Bounlieng Phommasouvanh

Minnesota Department of Education

Dr. Kalyani Rai

University of Wisconsin, Milwaukee

Dr. Soveacha Ros

Royal University of Phnom Penh

Dr. Nancy J. Smith-Hefner

Boston University

Dr. Christine Su

Ohio University

Dr. Loan Tran

University of California, Riverside

Dr. Tinou Tran

Alief Independent School District

Dr. Silvy Un

Frost Lake Elementary School

Dr. Terrence G. Wiley

Center for Applied Linguistics

Dr. Zha Blong Xiong

University of Minnesota

Dr. Kou Yang

California State University, Stanislaus

\section{Doctoral Student Editorial Review Board}

Sovicheth Boun

University of Texas at San Antonio

Keo Chea-Young

University of Pennsylvania

Peter Tan Keo

Columbia University

Minh Mai

University of Wisconsin-Madison

Hoa Nha Nguyen

Boston College

Vanna Som

Harvard University
Virak Chan

University of Texas at San Antonio

Annie BichLoan Duong

San Joaquin County Office of Education

Ravy Lao

University of California, Santa Barbara

Thien-Huong Ninh

University of Southern California

Malaphone Phommasa

University of California, Santa Barbara

Alisia Tran

University of Minnesota

Krissyvan Truong

Claremount Graduate University 